\title{
Polyelectrolyte Complex Based Nanocapsules Carrying Novel 5-Nitroindazole Thiazolidines with Potential Use in Treating Oral Infections
}

\author{
TONI ANDOR CIGU1,2,3, MIHAELA NICOLETA HOLBAN ${ }^{3}$, ANCA NICULINA CADINOIU ${ }^{3}$, VALERIU SUNEL ${ }^{2}$, CATALINA LIONTE ${ }^{4}$, \\ MARCEL POPA ${ }^{1,3,5 *}$, JACQUES DESBRIERES ${ }^{6}$, CORINA CHEPTEA ${ }^{7}$ \\ ${ }^{1}$ Gheorghe Asachi Technical University of lasi, Faculty of Chemical Engineering and Environmental Protection, Department of \\ Natural and Synthetic Polymers, Prof. dr. Docent Dimitrie Mangeron Avenue, 73, 700050, Iasi, Romania \\ ${ }^{2}$ Al. I. Cuza University of lasi, Faculty of Chemistry, 11 Carol I Blvd., 700506, Iasi, Romania, \\ ${ }^{3}$ Apollonia University of lasi, Faculty of Dental Medicine, 2 Muzicii Av., 700399, lasi, Romania \\ ${ }^{4}$ GigoreT. Popa University of Medicine and Pharmacy of lasi, Faculty of Medicine, 16 Universitatii Av., 700115, Iasi, Romania \\ ${ }^{5}$ Academy of Romanian Scientists, 54 Splaiul Independentei, 050094, Bucharest, Romania \\ ${ }^{6}$ Universite de Pau et des Pays de l'Adour, Institut Plurisdisciplinaire de Recherche sur l'Environnement et les Materiaux, \\ Equipe de Physique et Chimie des Polymères, IPREM, Helioparc Pau Pyrenees 2 Avenue P. Angot, 64053 PAU Cedex 09, France \\ ${ }^{7}$ Grigore T. Popa University of Medicine and Pharmacy of lasi, Faculty of Medical Bioengineering, 9-13 M. Kogalniceanu Av., \\ 700454, lasi, Romania
}

The aim of this research was the synthesis of novel 2,3-disubstituted 1,3 thiazolidines, derived from 5nitroindazole with antimicrobial activity and their encapsulation into polymer nanocapsules. Starting from previously synthesised hydrazones, there have been obtained novel thiazolidines by reaction with thioglycolic acid. The envisaged chemical structures were confirmed by spectral and elemental analysis. Two of the obtained thiazolidines were encapsulated into cationic Eudragit E100 nanocapsules, obtained by nanoprecipitation. In order to enhance drug release characteristics and particle stability, Eudragit E100 nanocapsules were covered with anionic polysaccharide (sodium alginate), thus forming a complex polyelectrolyte based membrane. The obtained nanocapsules presented a slower and more controlled drug release. The synthesized active principles, in free state and encapsulated into polymer nanocapsules, were tested for their acute toxicity and their influence on the development of model bacterial strains (Staphylococcus mutans, Actinobacillus actinomycetemcomitans, Bacillus subtilis, Bacillus cereus, Salmonella enteritidis, Escherichia coli and Staphylococcus aureus).

Keyword: polyelectrolyte, Eudragit E100, nanocapsules, sodium alginate, thiazolidine, antimicrobial

Among the high severity oral diseases periodontitis is most prominent. Periodontitis is the inflammation of the tissues supporting the teeth (periodontal) caused by infections and can lead to irreversible damage and teeth loss over time [1-3]. Periodontitis represents the evolved phase and/or the complication of gingivitis. The subgingival biofilm formation constitutes a plaque of over 500 bacterial species, being a complex ecological niche [4]. Under the influence of local and systemic factors, some bacteria present in subgingival biofilm become the primary etiological agents of periodontal disease. Such polymicrobial infections involve, in most cases, the Gramnegative anaerobic periodontal pathogens that act synergistically; bacteria such as Actinobacillus actinomycetemcomitans, Porphyromonas gingivalis, Prevotella intermedia, Bacteroides forsythus (Tannerella forsythensis) [5] and Streptococcus mutans (main causative agent of dental cavities) [6] are frequently involved.

The difficulty of eliminating these bacteria causes disease progression and poor response to treatments. As a result, periodontal pathogenic agents produce many virulence factors that facilitate the colonization of subgingival areas and increase the resistance to host defence mechanisms, ultimately leading to the destruction of the tissues supporting the teeth.

The mechanical removal of the dental biofilm and the elimination of the irritating factors constitute the base of periodontal therapy, with limits. Not all patients or dental regions respond favourably and uniformly to conventional mechanical therapy. Several factors (local or general) related to the host lead to the form and composition of biofilm that determines the decrease in efficacy of the applied therapy. Also, the pathogenic agents are not located only in the dental plaque, but also in the back area of the tongue or other parts of oral mucosa. Thus the applied therapy should affect all types of microorganisms existing in the bucopharyngeal cavity [7]. Considering the infectious nature of periodontitis and the limitations of mechanical scaling therapy, the use of antibiotics is justified in certain stages of the disease [1,3]. Antibiotic drugs can be administered locally and systemically, each approach presenting pros and cons. Therefore, the local application of antibiotics eliminates the risk of systemic adverse reactions, but there is still a possibility of recolonization of the treated areas if pathogen reservoirs are not completely eliminated.

The systemically administered antibiotics penetrate the periodontal pocket and attack the bacteria that are not affected by mechanical treatment or local therapy. Furthermore, they can suppress the pathogenic microorganisms located on the tongue surface and other areas of the oral cavity ensuring infection eradication and preventing recurrence. How ever, side effects, some of high severity, may appear.

\footnotetext{
* email: marpopa2001@yahoo.fr
} 
Besides antibiotics, many other compounds possess pharmaco-dynamic characteristics that are recommended in the treatment of diseases of the oral cavity as a result of interaction between certain functional groups in their composition and biological environment in which they are introduced.

Among these functional groups, responsible for determining biological activity, the indazole and the thiazolidine moieties are intensively studied. Usually, the compounds containing the indazole moiety present biological activity, such as anti-inflammatory $[3,8,9]$, antimicrobial [10-12], anti-HIV [13-15], anti-malaria [16]. The thiazolidine derivatives are well known as some of the most active pharmacological agents with antimicrobial [17-20] anticancerous [21], tuberculostatic [22], antiviral [23], anticonvulsant [24, 25], antimalarial [26], antioxidant effect [27, 28].

Thus, the synthesis of novel compounds containing both 4-oxo-thiazolidine and 5-nitroindazoles moieties for antimicrobial applications appear to be interesting and constitutes one of the goals of the present work.

Classical drug therapy often proves to be ineffective due to the non-discriminatory distribution of the biologically active principle, high systemic toxicity (especially in the case of antitumor), and their often high hydrophobicity or low tissues permeability. One way to avoid these adverse effects is to employ local targeted administration, using complex formulations, enabling a controlled and prolonged drug release. Besides this, an ideal formulation (dosage form) should exhibit good retention at application site. A long term retention at application site can be achieved by using bioadhesive formulations [29]. The most widely used periodontal dosage forms are films, inserts, gels, strips and micro/nanoparticles, each with its advantages and disadvantages [30]. The biodegradable, mucoadhesive nanoparticles are proving to be more effective, more convenient and easy to use than any other system used in the treatment of periodontitis [31]. Nanotechnology offers the opportunity of obtaining such systems in nano size, to be used as a support structure for loading drugs of different types of materials, such as carbon nanotubes [32, 33], fluorescent nanocrystals [34], nano-porous silica [35], dendrimers[36], liposomes [37, 38], graphenes [39], nanoemulsions [40], micelles [41] and polymer nanoparticles [42]. All of these types of nanosystems perform their goal of drug encapsulation and release at a target site (for example, the dentogingival junction), constituting real vehicles or vectors for various active principles.

Compared to other colloids used in dental applications, polymeric nanoparticles have several advantages, such as: better stability in biological fluids and during storage; easy preparation employing various techniques; facile largescale production, good reproducibility from batch to batch; good control of the amount of encapsulated drug; controlled release of the encapsulated/embedded active substances. Of course when entering the human body the polymers and the other ingredients that form the nanosystems must meet certain constraints: biocompatibility, biodegradability and the ability of forming nontoxic compounds etc.

Compared to polymer nanospheres, the empty systems (nanocapsules, nanovesicles) are preferred, due to their capacity to encapsulate high amounts of active principles. Nanocapsules membrane can be formed by using various techniques, the one which does not employ the use of often toxic covalent crosslinking agents (dialdehydes, epichlorhydrine etc.) being preferred. A convenient choice is represented by the use of polyanions/polycations pairs, able to form stable polyelectrolyte complex systems. An important variety of articles published in the Materiale Plastice journal have established optimal methods for obtaining different compounds (especially polymers), or stabilization and physico-chemical testing of high confidentiality [43-45]. They have been founded on complex models with a high degree of difficulty [46-48]. Undoubtedly, we can say that it is an important factor that led us to maintain high standards and publish the results of our research, here.

The present study aims at obtaining polymer nanocapsules, based on polyelectrolyte complex formed by Eudragit (polycation) and sodium alginate (polyanion), loaded with newly synthesized thiazolidines derivatives, solubilized into an oily vehicle (Mygliol), for the treatment of bacterial infections. The obtained nanosystems can be considered for potential applications in treating the bacterial infections that determine the occurrence of periodontitis.

\section{Experimental part}

\section{Materials and methods}

Eudragit E100 was purchased from Evonik Industries. Sodium alginate, Mygliol 840 oil, HPLC grade acetone, cetyltrimethylammonium bromide, dioxane, dimethylsulphoxide, thioglycolic acid, and zinc chloride were purchased from Sigma-Aldrich. All other reagents were used as received, without any purification. $N^{\prime}-(5-$ nitroindazole-1-yl-formyl)-N2-aryl-hydrazone (I-IV) was previously synthesized in our laboratory.

Synthesis of N-[(4-oxo-2-aryl-1,3-thiazolidine)- formamidyl]-5-nitroindazole (V-VIII)

In a reaction flask provided with a refluxing cooler, 0.005 mol N'-(5-nitroindazole-1-yl-formyl)-N2-aryl-hydrazone (IIV) is dissolved in $75 \mathrm{~mL}$ anhydrous dioxane, under mild heating. Then, equimolar quantities $(0.005 \mathrm{~mol})$ of thioglycolic acid and zinc chloride are added and the mixture is refluxed on a thermostated silicone bath for 6 hours, until obtaining a homogenous solution. The solvent excess is removed by low pressure distillation, until reaching a volume of approximately $15-20 \mathrm{~mL}$. A cream solid is separated after cooling and then it is vacuum filtered and dried. The product is purified by recrystallization from boiling ethanol. The final purification was performed using an alumina column, dichloromethane as solvent and a mixture of dichloromethane and isopropyl alcohol $(9 / 1 ; \mathrm{v} /$ v) as eluent.

The chemical structure of the obtained compounds was evaluated by elemental and spectral analysis (FT-IR and 1H-NMR).

\section{Preparation of Eudragit E100 nanocapsules}

Polymer nanocapsules were prepared by the interfacial deposition technique with slight modifications $[49,50]$.

Briefly, $0.2 \mathrm{~g}$ Eudragit E100 was first dissolved in $25 \mathrm{~mL}$ of acetone, containing $0.1 \mathrm{~g}$ cetyltrimethylammonium bromide, as cationic surfactant and $0.5 \mathrm{~mL}$ Miglyol 840 oil. The organic solution was poured drop-wise, under moderate magnetic stirring (500 rpm), into $50 \mathrm{~mL}$ distilled water. A milky nanosuspension was formed almost instantaneously due to the rapid diffusion of the acetone towards the aqueous phase. The acetone and a part of water phase were finally removed under reduced pressure (at rotary evaporator) and the particles suspension was concentrated to the desired final volume $(\sim 40 \mathrm{~mL})$. The formed nanocapsules contain the oily phase (Mygliol) surrounded by polycationic polymer. 
In a similar manner, polymer nanocapsules loaded with active principles are obtained, using $5 \mathrm{mg}$ thiazolidines dissolved into the initial organic phase.

Preparation of polyelectrolyte complex based nanocapsules A volume of sodium alginate solution $(0.1 \%$; w/v) was added to the previously prepared concentrated nanocapsules suspension ( $4 / 1 ; \mathrm{v} / \mathrm{v})$ and the mixture was left for curing overnight at $4^{\circ} \mathrm{C}$ and then placed in an ultracentrifuge ( $25000 \mathrm{rpm} ; 45 \mathrm{~min}$ ). The supernatant was analysed by laser light scattering in order to verify the presence of nanocapsules.

Nanocapsules and polyelectrolyte complex based nanocapsules characterization

Nanocapsules and polyelectrolyte complex based nanocapsules size was measured by laser light scattering (Zetasizer, Malvern Instruments, UK) on diluted suspensions of nanoparticles/ polyelectrolyte complex based nanocapsules in filtered (cellulose filter $0.45 \mu \mathrm{m}$ ) distilled water. Particles zeta potential was determined on diluted suspensions of particles into $0.1 \mathrm{M} \mathrm{KNO}_{3}$, prepared by adding 2-3 drops of particles suspensions into $5 \mathrm{~mL}$ (0.1M) $\mathrm{KNO}_{\text {s }}$ solution ( $p \mathrm{H} 7.2$ ). All determinations were made in triplicate.

\section{Determination of drug content into nanocapsules}

The practical amount of loaded drug was estimated as follows: $100 \mathrm{mg}$ of drug loaded nanocapsules was suspended in $100 \mathrm{~mL} \mathrm{~N}$-Methyl-2-pyrrolidone for $24 \mathrm{~h}$, under vigorous stirring, and then centrifuged ( $28000 \mathrm{rpm}, 45 \mathrm{~min}$ ). To ensure that the entire drug amount is leached out of the nanocapsules after $24 \mathrm{~h}$, the nanocapsules were suspended again into $50 \mathrm{~mL} \mathrm{~N}$-Methyl-2-pyrrolidone, and the extraction process was continued in a similar manner for another 24 h.

The UV absorbance of the supernatant was analysed using PG Instruments T60 UV-Vis spectrophotometer at $288 \mathrm{~nm}$ for N $\{[(4-0 \times 0-2$-( -nitrophenyl)-1,3-thiazolidine) ]formamidyl $\}-5$-nitroindazole (VII) and at $302 \mathrm{~nm}$ for $\mathrm{N}\{[(4-$ oxo-2-(o-hydroxy-phenyl)-1,3-thiazolidine) ]-formamidyl\}5-nitroindazole (VIII), respectively. Standard curves were obtained using solutions of active principles in N-Methyl-2pyrrolidone $(5-100 \mu \mathrm{g} / \mathrm{mL})$.

The efficiency of incorporating the active principle (AP) into the polymer nanocapsules was determined using the following equation (1).

$$
\% \text { loaded AP }=\frac{\text { practical amount of active principle }}{5 \mathrm{mg}} \times 100
$$

where $5 \mathrm{mg}$ represents the amount of active principale loaded into nanocapsules in the preparation stage.

\section{In vitro drug release}

The encapsulated active principle is insoluble in water and therefore for in vitro drug release tests it was necessary to use a nonaqueous solvent with aqueous buffered media as a cosolvent [51]. The prepared active principles $\mathrm{N}\{[(4-$ oxo-2-(p-nitrophenyl)-1,3-thiazolidine) ]-formamidyl\}-5nitroindazole- $A P$ VII and N $\{[(4-0 \times 0-2$-(o-hydroxy-phenyl)1,3-thiazolidine)]-formamidyl\}-5-nitroindazole - AP VIII) were found to be insoluble in water, poorly soluble in the prepared PBS and soluble in dimethyl sulfoxide, dimethylformamide and N-Methyl-2-pyrrolidone. Therefore, in order to simulate a release medium for insoluble drugs, an adequate quantity of water miscible solvent- $N$-Methyl2-pyrrolidone (a tenth of a volume of a mixture of phosphate buffer and N-Methyl-2-pyrrolidone) was used. N-Methyl-2- pyrrolidone is a water miscible, aprotic solvent and it has been reported to increase the solubility and permeability of several drugs [52]. It has low toxicity both orally and parenterally and can be used in formulations that require heat sterilization. These properties make N-Methyl-2pyrrolidone an attractive solubility enhancer in the pharmaceutical field [53, 54].

Taking into account the above mentioned statements, the ability to release the active principle was evaluated in PBS pH 7.2/ N-Methyl-2-pyrrolidone mixture (90/10; v/v), by calculating the percentage of released AP (\%) from the polymeric nanoparticles, using the following formula (2):

$$
\% \text { released } \mathrm{AP}=\frac{\text { amount of released } \mathrm{AP}}{\text { practical amount of } \mathrm{AP}} \times 100
$$

Standard curves were constructed by serial dilution of the stock solution of drug (N\{[(4-0xo-2-(p-nitrophenyl)1,3-thiazolidine)]-formamidyl\}-5-nitroindazole - AP VII and $\mathrm{N}\{[($ 4-oxo-2-(0-hydroxy-phenyl) -1,3-thiazolidine) ]formamidyl \}-5-nitroindazole - AP VIII) into PBS $\mathrm{pH} 7.2 / \mathrm{N}$ Methyl-2-pyrrolidone mixture (90/10; v/v), to obtain concentrations in the range of $5-100 \mathrm{ig} / \mathrm{mL}$. Absorbance values were depicted using a PG Instruments T60 UV-Vis spectrophotometer.

Drug release kinetics was evaluated as follows: $30 \mathrm{~mL}$ release medium (PBS pH 7.2/N-Methyl-2-pyrrolidone mixture (90/10; v/v)) was added on accurately weighted $20 \mathrm{mg}$ nanocapsules in capped beakers, containing small magnetic bars. The beakers were placed into water bath, thermostated at $37 \pm 0.5^{\circ} \mathrm{C}$ and left under moderate stirring (350 rpm). At predefined time intervals, samples of particle suspension were retrieved and were placed in an ultracentrifuge ( $28000 \mathrm{rpm}$; $45 \mathrm{~min})$. The resulted supernatant was then prelevated for determining the UVVis absorbance. AP release kinetics were expressed as released $A P(\%)$ in time.

\section{Determination of acute toxicity}

The acute toxicity values of the synthesized thiazolidines in free state or encapsulated into Eudragit E100 nanocapsules were determined by registering the median lethal dose (LD50) after intraperitoneal administration of suspensions (in Tween80) of free thiazolidines or thiazolidines loaded nanocapsules at groups of 10 white male mice weighing $20 \pm 2 \mathrm{~g}$ each. Before drug administration, mice were kept under observation for 7 days at constant temperature $\left(22^{\circ} \mathrm{C}\right)$, receiving habitual nourishment; animals were weighed every 2 days, those underweight being excluded from the experiment. The mortality of mice was registered at $24,48 \mathrm{~h}$ and 7 days after the administration of suspensions and LD50 was calculated using a modified Spearman-Karber arithmetic method equation (3) [55].

$$
L D_{50}=L D_{100} \frac{\sum(a \times b)}{n}
$$

where, $L D_{100}$ is the minimal drug dose which determines the death of all animals from a group; $a$ is the difference between two successive dosages administered to animals from different groups; $b$ is the mean number of dead animals from different groups, treated with successive dosages; and $\mathrm{n}$ is the number of dead animals from a group.

\section{Assessment of antibacterial activity}

Antimicrobial activity was evaluated using microbial strains cultivated on Mueller-Hinton agar and thermostated at $37^{\circ} \mathrm{C}$ for $18 \mathrm{~h}$, in contact with the product $(1000 \mu \mathrm{g} / \mathrm{mL})$ as discs of $1000 \mu \mathrm{g}$ each, according to Kirby-Bauer Diffusion 


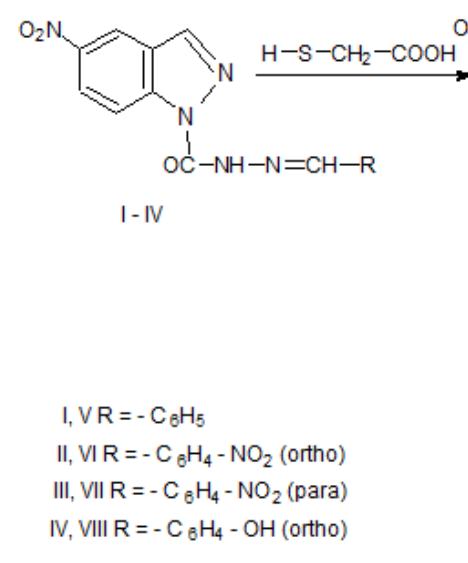

or

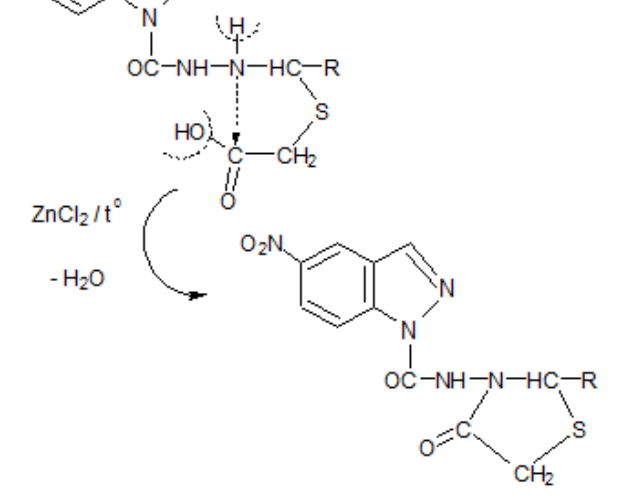

V- VIII

method [56]. The diameter of inhibition area was noted and the results were expressed, considering that for less than $16 \mathrm{~mm}$ of diameter the product has no antimicrobial activity, at 16-18 mm, it has a moderate activity and good activity over $18 \mathrm{~mm}$, respectively.

\section{Results and discussions}

Synthesis and characterization of novel thiazolidines

Starting from a series of previously synthesized hydrazones derivatives (N1-(5-nitroindazole-1-il-formyl)N2-aryl-hydrazones I-IV) [57], novel thiazolidines have been synthesized by reaction with thioglycolic acid, in the presence of anhydrous zinc chloride, as dehydrating agent.

The cyclization mechanism implies the formation in the first step of hydrazone-thioacid, which is then transformed into 2,3-disubstituted thiazolidine by eliminating one molecule of water simultaneously with the nucleophilic attack of nitrogen on the carbonyl from the thioacid group. The compounds were purified by recrystallization from ethanol. A final purification was performed on alumina column, using dichloromethane as solvent and dichloromethane/isopropyl alcohol $(9 / 1 ; \mathrm{v} / \mathrm{v})$ as an eluent. The synthesized compounds (V-VIII) were obtained with a yield of 61-76\%; they are cream coloured, crystalline substances with fixed melting points. The imagined chemical structure of the compounds was proven by elemental and spectral analysis (FT-IR and 1H-NMR).

FT-IR spectra present a medium intensity band at 2959$2979 \mathrm{~cm}^{-1}$, specific for N-CH-S bonds vibrations, an intense absorption at 3084-3179 $\mathrm{cm}^{-1}$, specific for the vibrations of aromatic $\mathrm{CH}$. The aromatic $\mathrm{C}=0$ is shown by the band at $1700-1710 \mathrm{~cm}^{-1}$, and at the bands appearing at $664-751$ $\mathrm{cm}^{-1}$ are specific for $\mathrm{C}-\mathrm{S}-\mathrm{C}$ bond vibrations. NO groups are identified by symmetric vibrations band at $1340-1388 \mathrm{~cm}$. ${ }^{1}$ and asymmetric vibrations band at $1515-1587 \mathrm{~cm}^{-1}$, respectively. In ${ }^{1} \mathrm{H}-\mathrm{NMRspectra}$ of thiazolidines (V-VIII) the position and the intensity of the specific signals correspond to the supposed chemical structures of the analysed compounds. Signals of $\mathrm{NH}$ proton at 8.83-8.96 ppm, of $\mathrm{CH}_{2}$ protons from the thiazolidine ring at 5.33-5.39 ppm were present. The aromatic protons are identified at 7.20-8.51 $\mathrm{ppm}$ and the ones corresponding to the $\mathrm{OH}$ group (thiazolidine VIII) are seen as a singlet signal at $11.70 \mathrm{ppm}$.

The physicochemical and spectral characteristics and also the elemental compositions of the 4 synthesized thiazolidines are presented as follows, proving the obtaining of the envisaged compounds.

N-[(4-oxo-2-phenyl-1,3-thiazolidine)- formamidyl]-5nitroindazole $(V)$. Cream solid ( 1.16 ; vield, \%: 61), melting point: 199-201 ${ }^{\circ} \mathrm{C}$. FT-IR; $\left(v_{m 2 x} ; \mathrm{Cm}^{-1}\right): 3120(\mathrm{CH}, \mathrm{Ar}) ; 2959$ (N-CH-S); 1702 (cycle C=0); 1677 (amide C=0); 1618
Fig. 1. Synthesis of N-[(4-0xo-2-aryl-1,3thiazolidine)-formamidyl]-5-nitroindazole (V-VIII) starting from N1-(5-nitroindazole1-il-formyl)-N2-aryl-hydrazones (I-IV) (cycle $\mathrm{N}=\mathrm{CH}) ; 1384$ (sym. NO $)_{2}$; 1520 (asym. NO $)$ ); 1497 $\left(\mathrm{N}-\mathrm{CH}_{2}\right) ; 751$ (C-S-C). ${ }^{1} \mathrm{H}-\mathrm{NMR}\left(\mathrm{DMSOOd}^{2}, 400 \mathrm{MHz}\right) \delta^{2}(\mathrm{ppm})$ : $5.33\left(\mathrm{~s}, 2 \mathrm{H}, \mathrm{CH}_{2}\right), 6.78(\mathrm{~s}, 1 \mathrm{H}, \mathrm{CH}), 6.96-7.00(\mathrm{~d}, 2 \mathrm{H}, \mathrm{CH} \mathrm{Ar})$, 7.18-7.22 (d, $1 \mathrm{H}, \mathrm{CH} \mathrm{Ar}), 7.6-7.62(\mathrm{~d}, 1 \mathrm{H}, \mathrm{CH} \mathrm{Ar}), 7.72-7.74$ ( $m, 3 \mathrm{H}, \mathrm{CH} \mathrm{Ar}), 8.40(\mathrm{~s}, 1 \mathrm{H}, \mathrm{CH} \mathrm{Ar}), 8.50(\mathrm{~s}, 1 \mathrm{H}, \mathrm{CH} \mathrm{Ar}), 8.92$ (s, $1 \mathrm{H}, \mathrm{NH}$ ). Anal. calcd. for $\mathrm{C}_{17} \mathrm{H}_{13} \mathrm{O} \mathrm{S}(\%)$ : C, 53.26\%; $\mathrm{H}$, 3.39\%; N, 18.27; S, 8.35\%. Found: C, 53.38\%; H, 3.66\%; N, 18.58; S, $8.76 \%$.

$N\{[(4-0 \times 0-2-(0-n i t r o-p h e n y l)-1,3-t h i a z o l i d i n e)]-$ formamidyl\}-5-nitroindazole (VI). White solid ( $1.45 \mathrm{~g}$; yield, $\%: 68)$, melting point: $170-172{ }^{\circ} \mathrm{C}$. FT-IR $\left(\mathrm{v} ; \mathrm{Cm}^{-1}\right): 3179$ ( $\mathrm{CH}$ Ar); 2979 (N-CH-S); 1710 (cycle $\mathrm{C}=0$ ), ${ }^{\text {max }}$, 1660 (amide $\mathrm{C}=0$ ); 1615 (cycle $\mathrm{N}=\mathrm{CH}$ ); 1340 (sym. $\mathrm{NO}$,); 1580(asym. $\left.\mathrm{NO}_{2}\right) ; 1484\left(\mathrm{~N}-\mathrm{CH}_{2}\right) ; 670$ (C-S-C). ${ }^{1 H}$-NMR (DMSO-d6, 400 $\left.\mathrm{MHZ}^{2}\right), \delta(\mathrm{ppm}): 5.33\left(\mathrm{~s}, 2 \mathrm{H}, \mathrm{CH}_{2}\right) ; 6.82(\mathrm{~s}, 1 \mathrm{H}, \mathrm{CH}) ; 6.93-$ 6.95 (d, 2H, CH Ar); 7.21-7.24 (d, $1 \mathrm{H}, \mathrm{CH} \mathrm{Ar}$ ); 7.51-7.54 (d, $1 \mathrm{H}, \mathrm{CH} \mathrm{Ar}) ; 7.76-7.78(\mathrm{~d}, 2 \mathrm{H}, \mathrm{CH} \mathrm{Ar}) ; 8.33(\mathrm{~s}, 1 \mathrm{H}, \mathrm{CH} \mathrm{Ar})$; $8.45(\mathrm{~s}, 1 \mathrm{H}, \mathrm{CH} \mathrm{Ar}) ; 8.33(\mathrm{~s}, 1 \mathrm{H}, \mathrm{NH})$. Anal.calcd. for $\mathrm{C}_{17} \mathrm{H}_{12} \mathrm{~N}_{6} \mathrm{O} \mathrm{S}(\%): \mathrm{C}, 47.66 ; \mathrm{H}, 2.80 ; \mathrm{N}, 19.62 ; \mathrm{S}, 7.47 \%$. Found: C, 47.95; H, 3.02; N, 19.95; S, 7.84.

$N\{[(4-0 \times 0-2-(p-n i t r o-p h e n y l)-1,3$-thiazolidine $)]-$ formamidyl\}-5-nitroindazole (VII). Cream solid (1.58 g; yield, \%: 74), melting point: 106-108 ${ }^{\circ} \mathrm{C}$. FT-IR $\left(v_{\text {max }} ; \mathrm{Cm}^{-1}\right)$ : 3084 (CH Ar); 2970 (N-CH-S); 1700 (cycle C=O8x); 1684 (amide $\mathrm{C}=0) ; 1614$ (cycle $\mathrm{N}=\mathrm{CH}) ; 1388$ (sym. $\mathrm{NO}_{2}$ ); 1587(asym. NO $)$; $1495\left(\mathrm{~N}-\mathrm{CH}_{2}\right) ; 689$ (C-S-C). ${ }^{1} \mathrm{H}-\mathrm{NMR}$ (DMSO-d6, $400 \mathrm{MHz}), \delta(\mathrm{ppm}): 5.35\left(\mathrm{~s}, 2 \mathrm{H}, \mathrm{CH}_{2}\right) ; 6.74(\mathrm{~s}$, $1 \mathrm{H}, \mathrm{CH}) ; 6.94-6.98$ (d, 2H, CH Ar); 7.20-7.24 (d, $1 \mathrm{H}, \mathrm{CH} \mathrm{Ar}$ ); 7.59-7.61 (d, $1 \mathrm{H}, \mathrm{CH} \mathrm{Ar}) ; 7.75-7.80(\mathrm{~d}, 2 \mathrm{H}, \mathrm{CH} \mathrm{Ar}) ; 8.44(\mathrm{~s}$, $1 \mathrm{H}, \mathrm{CH} \mathrm{Ar}) ; 8.51(\mathrm{~s}, 1 \mathrm{H}, \mathrm{CH} \mathrm{Ar}) ; 8.96(\mathrm{~s}, 1 \mathrm{H}, \mathrm{NH})$. Anal. calcd. for $\mathrm{C}_{17} \mathrm{H}_{1} \mathrm{~N}_{0} \mathrm{OS}(\%)$ : $\mathrm{C}, 47.66 ; \mathrm{H}, 2.80 ; \mathrm{N}, 19.62 ; \mathrm{S}, 7.47 \%$. Found: C, $47.85 ; \mathrm{H}, 3.04 ; \mathrm{N}, 19.72 ; \mathrm{S}, 7.62$.

$N\{[(4-0 \times 0-2-(0-h y d r o x y-p h e n y l)-1,3$-thiazolidine) ]formamidy|\}-5-nitroindazole (VIII). Light cream solid (1.50 g; yield, \%: 76), melting point: 188-190 ${ }^{\circ} \mathrm{C}$. FT-IR $\left(v_{\text {max }} ; \mathrm{Cm}^{-}\right.$ 1): 3140 (CH Ar); 2977 (N-CH-S); 1710 (cycle C=0); 1675 (amide $\mathrm{C}=0$ ); $1617($ cycle $\mathrm{N}=\mathrm{CH}) ; 1346$ (sym NO ); 1515 (asym NO $) ; 1421\left(\mathrm{~N}_{2} \mathrm{CH}_{2}\right) ; 664(\mathrm{C}-\mathrm{S}-\mathrm{C}) .{ }^{1} \mathrm{HNM} \mathrm{R}^{2}$ (DMSO-d6, $400 \mathrm{MHz}), \delta(\mathrm{ppm}): 5.39(\mathrm{~s}, 2 \mathrm{H}, \mathrm{CH} 2) ; 6.84(\mathrm{~s}$, $1 \mathrm{H}, \mathrm{CH}) ; 6.90-6.92$ (d, 2H, CH Ar); 7.24-7.26 (d,1H, CH Ar); 7.55-7.57 (d, $1 \mathrm{H}, \mathrm{CH} \mathrm{Ar}) ; 8.37(\mathrm{~s}, 1 \mathrm{H}, \mathrm{CH} \mathrm{Ar}) ; 8.48(\mathrm{~s}, 1 \mathrm{H}$, $\mathrm{CH} \mathrm{Ar}): 8.84(\mathrm{~s}, 1 \mathrm{H}, \mathrm{NH}) ; 11.70(\mathrm{~s}, 1 \mathrm{H}, \mathrm{OH})$. Anal.calcd. for C17H13N505S (\%): C, 51.12; H, 3.25; N, 17.54; S, 8.02\%. Found: C, 51.40; H, 3.42; N, 17.80; S, 8.34.

The synthesized thiazolidines present chirality, determined by the presence of an asymmetric carbon into the cycle. As the antimicrobial tests on these compounds proved both enantiomers to be biologically active, we were not interested to determine whether this characteristic is due to a certain optical isomer, therefore, the research was done using the compounds as resulted from synthesis. 
The preparation and characterization of nanocapsules

In order to obtain nanocarriers able to include higher amounts of active principles, the polymer nanocapsules were chosen for the drug delivery system.

Nanocapsules were synthesized based on EudragitE100, which is a cationic synthetic polymer, swellable and permeable above $\mathrm{pH}$ 5.0, used mostly as drug carrier [5860]. In order to enhance the cationic induced characteristics, a highly cationic surfactant ( cetyltrimethylammonium bromide - CTAB) was used for nanocapsules preparation. CTAB is a non-toxic surfactant, effective as antiseptic agent against bacteria and fungi. The method employed for nanocapsules obtaining is a simple, reproducible technique [58], the use of an oily vehicle (ex. benzyl alcohol, Mygliol etc.) into the organic phase ensuring the preparation of nanocapsules (core-shell structures) with the respective oily core $[49,61]$. In this case, Mygliol 840 was used to form the oily core (containing the drug) of the nanocapsules.

Nanocapsules stability can be augmented by deposing a polyanion on their surface, forming with Eudragit a polyelectrolytic complex type membrane. Thus, the use of an anionic polysaccharide contributes not only to the increase of particle stability, but also to the increase of nanocapsules mucoadhesivity, which is an important characteristic for the desired application. Various polymers (e.g. sodium alginate, sodium carboxymethylcellulose, guar gum, hydroxyethylcellulose, karya gum, methylcellulose, polyethylene glycol (PEG), retene and tragacanth, chitosan etc.) have been found to exhibit mucoadhesive properties and have been studied as oral drug carriers [62, 63].

Sodium alginate, an anionic non-toxic polysaccharide is widely used in food industry, medicine and pharmacology. Consequently, in order to prepare stable nanocapsules with pronounced muchoadhesivity, sodium alginate was deposited onto positively charged nanocapsules surface (charge given by Eudragit and cationic surfactant), thus, forming by electrostatic interactions, a polyelectrolyte membrane.

The size, size distribution and zeta potential of the prepared nanocapsules were evaluated. The average diameter of empty nanocapsules was found to be around $138 \mathrm{~nm}$ (table 1), presenting medium size polydispesity.

Evidently, the deposition of a novel polymer layer (sodium alginate) onto empty nanocapsules determines the increase of particle diameter, placing it around $150 \mathrm{~nm}$

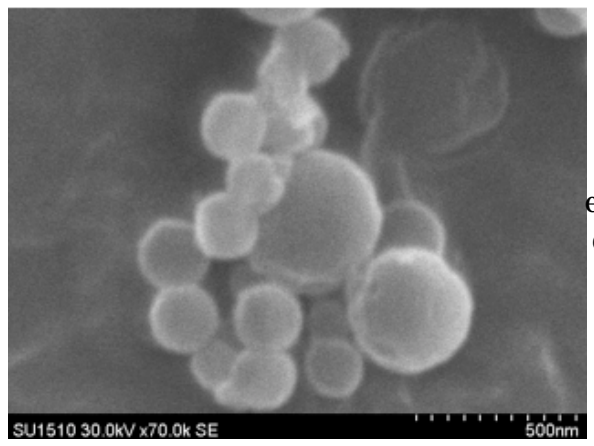

Fig. 2. Scanning electron micrograph of alginate covered Eudragit E100 nanocapsules

(table 1), as well as, an augmentation of particle size polydispersity, as shown by SEM image (fig. 2).

The topical administration (on gingival mucosa) by injection of the nanocapsules loaded with active principles, requires that the systems have reduced size and adequate stability as suspensions in physiological liquid media. These characteristics have been verified by evaluating the zeta potential of the nanocapsules, high values being registered $(50.1 \mathrm{mV})$, due to numerous positively charged groups found on nanocapsules surface (table 1).

The efficiency of drug loading was evaluated, by drug extraction into $N$-Methyl-2-pyrrolidone mixture for $100 \mathrm{~h}$ from both EudragitE100 and polyelectrolyte nanocapsules.

\begin{tabular}{|c|c|c|c|c|}
\hline Sample & Size (nm) & $\begin{array}{c}\text { Polydispersity } \\
\text { index }\end{array}$ & $\begin{array}{c}\text { Zeta potential } \\
(\mathbf{m} \boldsymbol{V})\end{array}$ & $\begin{array}{c}\text { Zeta deviation } \\
(\mathbf{m} \boldsymbol{V})\end{array}$ \\
\hline Eudragit E100 Nanocapsules & 138 & 0.143 & 50.1 & 6.81 \\
\hline $\begin{array}{c}\text { Nanocapsules covered with } \\
\text { sodium alginate }\end{array}$ & 153 & 0.237 & -45.4 & 7.78 \\
\hline
\end{tabular}

Table 1

SIZE, POLYDISPERSITY INDEX AND ZETA POTENTIAL OF PREPARED NANOCAPSULES

\begin{tabular}{|l|l|c|}
\hline \multicolumn{1}{|c|}{ Loaded active principle } & \multicolumn{1}{|c|}{ Polymer system } & Loaded AP, \% \\
\hline $\begin{array}{l}\text { N }\{[(4-\text { oxo-2-(p-nitropheny1)-1,3- } \\
\text { thiazolidine)]-formamidyl }\}-5- \\
\text { nitroindazole (VII) }\end{array}$ & Eudragit E100 nanocapsules & 98 \\
\cline { 2 - 3 } $\begin{array}{l}\text { N }\{[(4-\text { oxo-2-(o-hydroxy-pheny1)-1,3- } \\
\text { thiazolidine)]-formamidyl }\}-5-\end{array}$ & Polyelectrolyte systems & 89 \\
nitroindazole (VIII) & Eudragit E100 nanocapsules & 95 \\
\cline { 2 - 3 } & Polyelectrolyte systems & 91 \\
\hline
\end{tabular}

Table 2

LOADING EFFICIENCY OF ACTIVE PRINCIPLES

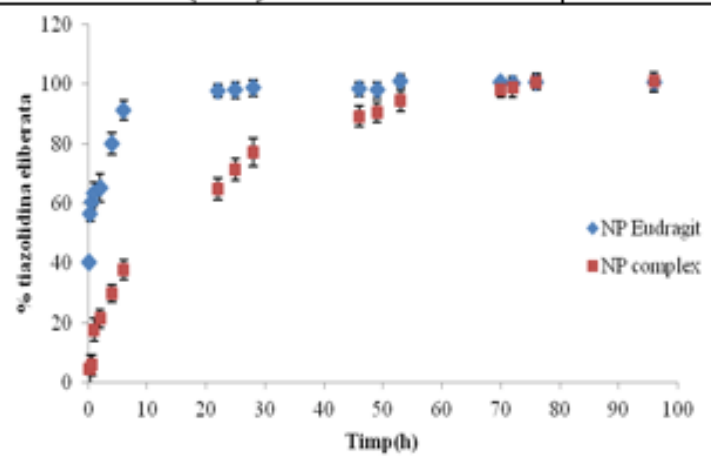

Fig. 3. In vitro tiazolidine VII release profile from Eudragit E100 nanocapsules and polyelectrolyte systems

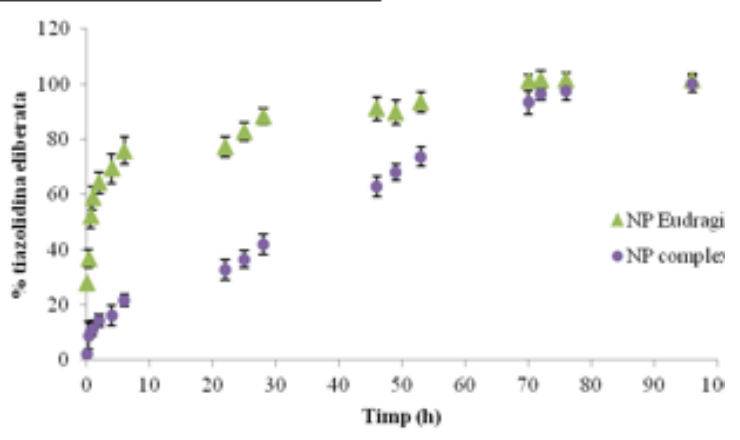

Fig. 4. In vitro tiazolidine VIII release profile from Eudragit E100 nanocapsules and polyelectrolyte systems 
Table 3

ACUTE TOXICITY OF THIAZOLIDINES (V-VIII) AND THIAZOLIDINES (VII-VIII) LOADED INTO NANOCAPSULES

\begin{tabular}{|l|r|r|r|c|}
\hline \multirow{2}{*}{ Compound } & \multicolumn{3}{|c|}{ LD 50 (mg/kg) } \\
\cline { 2 - 5 } & $\mathbf{2 4}$ hours & $\mathbf{4 8}$ hours & $\mathbf{7}$ days & Average \\
\hline V & 1100 & 1100 & 1090 & 1096 \\
\hline VI & 1120 & 1120 & 1105 & 1115 \\
\hline VII & 1310 & 1310 & 1295 & 1305 \\
\hline VIII & 1585 & 1585 & 1542 & 1570 \\
\hline VI encapsulated into polymer nanocapsules & 4715 & 4715 & 4690 & 4706 \\
\hline VI encapsulated into polyelectrolyte systems & 4850 & 4800 & 4800 & 4810 \\
\hline VII encapsulated into polymer nanocapsules & 5020 & 5020 & 5080 & 5040 \\
\hline VII encapsulated into polyelectrolyte systems & 5000 & 5000 & 5000 & 5000 \\
\hline
\end{tabular}

Table 4

ANTIMICROBIAL ACTIVITY OF THIAZOLIDINES AND THIAZOLIDINES LOADED INTO NANOCAPSULES

\begin{tabular}{|c|c|c|c|c|c|c|c|}
\hline \multirow{2}{*}{ Compound } & \multicolumn{7}{|c|}{ Diameter of the inhibition area (mm) } \\
\hline & $\begin{array}{c}\text { S. } \\
\text { aureus }\end{array}$ & $\begin{array}{l}\text { B. } \\
\text { subtilis }\end{array}$ & $\begin{array}{l}\text { B. } \\
\text { cereus }\end{array}$ & $\begin{array}{l}E \text {. } \\
\text { coli }\end{array}$ & $\begin{array}{c}S . \\
\text { enteritidis }\end{array}$ & $\begin{array}{c}\text { S. } \\
\text { mutans }\end{array}$ & $\begin{array}{c}\text { A. } \\
\text { actinomycetem } \\
\text { comitans }\end{array}$ \\
\hline $\mathrm{V}$ & $7-8$ & $18-19$ & $19-20$ & $11-12$ & $16-17$ & $17-18$ & $18-19$ \\
\hline VI & $8-9$ & $19-20$ & $18-19$ & $14-15$ & $18-19$ & $17-18$ & $18-19$ \\
\hline VII & $6-7$ & $21-22$ & $19-20$ & $13-14$ & $19-20$ & $19-20$ & $23-24$ \\
\hline VII & $7-8$ & $20-21$ & $20-21$ & $12-13$ & $19-20$ & $22-23$ & $23-24$ \\
\hline $\begin{array}{l}\text { VII encapsulated into } \\
\text { nanocapsules }\end{array}$ & $9-10$ & $23-24$ & $22-23$ & $15-16$ & $20-21$ & $24-25$ & $25-26$ \\
\hline $\begin{array}{l}\text { VII encapsulated into } \\
\text { polyelectrolyte systems }\end{array}$ & $9-10$ & $24-25$ & $22-23$ & $16-17$ & $20-21$ & $24-25$ & $25-26$ \\
\hline $\begin{array}{l}\text { VIII encapsulated into } \\
\text { nanocapsules }\end{array}$ & $10-11$ & $25-26$ & $23-24$ & $16-17$ & $23-24$ & $26-27$ & $25-26$ \\
\hline $\begin{array}{l}\text { VIII encapsulated into } \\
\text { polyelectrolyte systems }\end{array}$ & $11-12$ & $25-26$ & $24-25$ & $15-16$ & $23-24$ & $26-27$ & $26-27$ \\
\hline Kanamicyn & $31-32$ & $27-28$ & $30-31$ & $29-30$ & $28-29$ & $32-33$ & $33-34$ \\
\hline
\end{tabular}

The loading efficiency appears to be quite high, even after complexation of EudragitE100 nanocapsules with sodium alginate (table 2).

Small loss of drug is registered by covering the Eudragit E100 nanocapsules with sodium alginate, probably during ultracentrifugation. The loss of drug in such reduced quantities is probably due to the insolubility of the prepared active principles in water and poor solubility in PBS solution.

The in vitro drug release profiles were depicted, using as release medium a mixture of phosphate buffer and $N$ Methyl-2-pyrrolidone (90/10, v/v) in order to enhance drug solubility. The entire amount of thiazolidine VII loaded into polyelectrolyte nanocapsules leached out after $72 \mathrm{~h}$ (UVVis analysis showed no drug traces after $72 \mathrm{~h}$ of drug extraction into PBS pH 7.2/ N-Methyl-2-pyrrolidone mixture) while from EudragitE100, the entire amount of compound VII was expulsed after only 46 hours (fig.3).

Approximately $95 \%$ of the loaded thiazolidine VIII was released after 66 hours from Eudragit E100 based nanocapsules and after $70 \mathrm{~h}$ from polyelectrolyte systems (fig. 4).

The electrostatic interactions between the cationic nanocapsules, and sodium alginate, and the formed polyelectrolyte complex type membrane, respectively, determined a slower drug release for a longer period of time. Thus, the initial rapid release profile (burst-effect), specific for polymer/polysaccharide biomaterials no is longer evident in the case of polyelectrolyte systems.
Thiazolidine VIII is released from electrolyte complex based nanoparticles following zero order kinetics, which represents an ideal situation for controlled and sustained drug delivery systems.

The applications of any biomaterial are restrained by their possible toxic effects in animal organisms. The prepared polymer systems are covered by mucoadhesive layer, have small size and present sustained drug release profiles. Therefore, they could be used as drug vehicles in oral, gastrointestinal, ocular applications etc., for both local and systemic administration of the enclosed active principle.

In this work, the acute toxicity of synthesized thiazolidines (V-VIII) and thiazolidines (VII-VIII) loaded into nanocapsules was evaluated, determining the LD50 in mice, by intraperitoneal administration. The tests on animals were performed with respect to the ethical standards claimed in Helsinki Declaration of 1975, as revised in 2000, as well as the national laws and the work has been approved by Research Ethics Committee from Apollonia University of lasi.

The obtained results are presented in table 3.

According to the Hodge and Sterner toxicity scale [64] all synthesized thiazolidines were slightly toxic and Eudragit E100 nanocapsules containing thiazolidine VII or VIII were registered as practically non-toxic. LD50 shows 
a visible increase by encapsulating the thiazolidines into polymer nanocapsules.

Antimicrobial activity of the thiazolidines whether encapsulated or not, was evaluated according to NCCLS international standards National Committee for Clinical Laboratory Standards on various model bacterial strains (table 3), two of which are usually found in the oral cavity. The diameter of the inhibition area was registered.

Knowing the fact that only diameters over $16 \mathrm{~mm}$ can be considered as adequate for bacterial development inhibition/antimicrobial activity, thiazolidines V-VIII were found to be active against the development of $B$. subtilis, $B$. cereus, S. enteritidis, S.mutans and A. actinomycetem comitans, moderately efficient against $E$. coli (compound VIII) and presented no activity against the development of $S$. aureus. It has been shown that $B$. cereus, $B$. subtilis and $S$. enteritidis strains are more sensitive to the presence of $\mathrm{NO}_{2}$ and $-\mathrm{OH}$ substitute groups from thiazolidines $\mathrm{VII}$ and $\mathrm{VIII}^{2}$, as compared to thiazolidines $\mathrm{V}$ and $\mathrm{VI}$. Also, antibacterial efficiency seemed to improve by encapsulating the active principles into the polyelectrolyte nanocapsules. As compared to kanamycin (reference antibiotic drug), the synthesized thiazolidines (VII and VIII) present lower biologic activity, but with the advantages corresponding to drug delivery systems (less toxic, smaller dosage, application at the desired site, less adverse effects etc.).

\section{Conclusions}

Novel 2,3-disubstituted 1,3 thiazolidines derived from 5-nitroindazole have been synthesized and encapsulated into EudragitE100 based nanocapsules of $130 \mathrm{~nm}$ diameter, covered with sodium alginate. The chemical structure of the prepared thiazolidines was confirmed by both elemental and spectral analysis. The acute toxicity and the influence of thiazolidines (in free state and encapsulated into polymer nanocapsules) on the inhibition of the development of oral bacterial strains were tested. The polyelectrolyte complex formed between the cationic nanocapsules and the anionic alginate determined a slower and a more controlled drug release

\section{References}

1. KONG, L. X., PENG Z., Li S. D., BARTOLD P.M., Periodontol., 40, 184, 2006, p. 184.

2.BRYERS, J. D. and RATNER B. D., BMC Oral Health, 6, 2006, S15. 3.FARSHORI, N. N., BANDAY, M. R., AHMAD, A., KHAN A. U., RAUF A., Bioorg. Med. Chem. Lett., 20, 2010, p.1933.

4.PETERSON, S. N., SNESRUD E., LIU J ., ONG A.C., KILIAN M., SCHORK N. J., BRETZ W., PLoS One, 8, 2013, e58487.

5.GUTHMILLER, J. M. and NOVAK, K. F., in Polymicrobial Diseases edited by K. A. Brogden and J. M. Guthmiller, ASM Press, 2002, chapter 8.

6.METWALLI, K. H., KHAN S. A., KROM B. P., JABRA-RIZK M. A., PLOS Pathog., 9, 2013, e1003616.

7.SHIRTLIFF V. J. and HENCH L. L., J. Mat. Sci., 38, 2003, p. 4697

8.CHEPTEA, C., DULCESCU, M. M., DOROHOI, D. O., SUNEL, V. DESBRIERES, J., Dig. J. Nanomat. Biostruct., 7, 2012, p. 287.

9.CHEPTEA, C., a UNEL, V., HOLBAN, M., DESBRIERES, J., POPA, M., LIONTE, C., Cell. Chem. Technol., 46, 2012, p.19

10.UPADHYAY, A., SRIVASTAVA, S. K. and SRIVASTAVA, S. D., Eur. J. Med. Chem., 45, 2010, p. 3541.

11.CHEPTEA, C., HOLBAN, M., PEPTU, C., LIONTE, C., SUNEL, V., POPA, M., DESBRIERES, J., Cell. Chem. Technol., 47, 2013, p. 23. 12.LIU, W., NEIDERT, M. C., GROEN, R. J. M., WOERNLE, C. M., GRUNDMANN H., Clin. Neurol. Neurosurg., 116, 2014, p. 13.

13.SUN, J. H., TELEHA, C. A., YAN, J. S., RODGERS J. D., NUGIEL D. A., J. Org. Chem., 62, 1997, p.5627.
14.KORTH-BRADLEY, J. M., BAIRD-BELLAIRE, S.J ., PATAT, A.A., J. Clinic. Pharmacol., 51, 2011, p. 93.

15.QUESADA-MOLINA, C., GARCÍA-CAMPAÑA, A. M., DEL OLMOIRUELA, M., Talanta, 15, 2013, p.943.

16.MELNYK, P., LEROUX, V., SERGHERAERT, C., GRELLIER, P., Bioorg. Med. Chem. Lett., 16, 2006, p. 31.

17.BOZDAD-DÜNDAR, O., OZGEN, O., MENTEPE, A., ALTANLAR, N., ATLI, O., KENDI, E., ERTAN, R., Bioorg. Med. Chem., 15, 2007, p. 6012. 18.SHIRADKAR, M. R., MURAHARI, K. K., GANGADASU, H. R., SURESH, T., KALYAN, C. A., PANCHAL, D., KAUR, R., BURANGE, P., GHOGARE, J., MOKALE, V., RAUT M., Bioorg. Med. Chem., 15, 2007, p. 3997.

19.GOUVEIA, F. L., DE OLIVEIRA, R. M. B., DE OLIVEIRA T. B., Eur. J. Med. Chem., 44, 2009, p. 2038.

20.HAVRYLYUK, D., ROMAN, O. and LESYK, R., European J Med Chem, 113,2016, p.145.

21.CHEN, J., WANG, Z., LU, Y., DALTON, J. T., MILLER, D. D., LI, W., Bioorg. Med. Chem. Lett, 18, 2008, p.3183.

22.KARALI, N., GÜRSOY, A., KANDEMIRLI, F., SHVETS, N., KAYNAK, F. B., OZBEY, S., KOVALISHYN, V., DIMOGLO, A., Bioorg. Med. Chem., 15,2007, p.5888.

23.KAUSHIK-BASU, N., BOPDA-WAFFO, A., TALELE, T.T., BASU, A., CHEN, Y., KUCUKGUZEL, S.G., Front. Biosci., 13, 2008, p. 3857.

24.AGARWAL, A., LATA, S., SAXENA, K. K., SRIVASTAVA, V. K. and KUMAR, A., Eur. J. Med. Chem., 41, 2006, p. 1223.

25.AMIN, K. M., RAHMAN, D. E., AL-ERYANI, Y. A., Bioorg. Med. Chem., 16, 2008, p. 5377.

26.SOLOMON, V. R., HAQ, W., SRIVASTAVA, K., PURI, S. K., KATTI, S. B., J. Med. Chem., 50, 2007, p. 394.

27.DA SILVA, T.L., MIOLO, L.M.F., SOUSA, F.S., BROD, L.M., SAVEGNAGO, L., SCHNEIDER, P.H., Tetrahedron Lett., 56, 2015, p.6674. 28.SHIH, M. H., KE, F. Y., Bioorg. Med. Chem., 12, 2004, p. 4633.

29.PATTNAIK, S., PANIGRAHI, L., MURTHY R. S., Curr. Drug. Deliv., 4, 2007, p. 303.

30.PRAGATI S., ASHOK S., KULDEEP S., Int. J. Drug. Deliv., 1, 2009, p. 1.

31.SAPRA, P., PATEL, B. D., PATEL, D. V., BORKHATARIA, C. H., Int. J . Pharm. Chem. Anal., 1, 2014, p.65.

32.KIRIMLIOĐLU, G. Y., YAZAN, Y., EROL, K., ÜNEL, Ç. Ç., Int. J. Pharm., 495, 2015, p. 816.

33.YAO, H. J., ZHANG, Y. G., SUN L., LIU, Y., Biomat. 35, 2014, p. 9208. 34.GHADERI, S., RAMESH, B., SEIFALIAN, A. M., J. Drug. Target., 19, 2011, p. 475.

35.HESSE, D., EHLERT, N., LUBENHOP, T., Otol. Neurotol., 34, 2013, p. 1138.

36.CHAMORRO C., BOERMAN M. A., ARNUSCH C. J., BREUKINK, E., PIETERS, R. J., B.B.A. - Biomembranes, 1818, 2012, p. 2171.

37.VANNIASINGHE, A.S., MANOLIOS, N., SCHIBECI, S., LAKHIANI, C., KAMALI-SARVESTANI, E., SHARMA, R., KUMAR, V., MOGHADDAM, M, ALI, M., BENDER, V., Clin. Immunology, 151, 2014, p.43.

38.NGUYEN, S., HIORTH, M., RYKKE, M., SMISTAD, G., Eur J Pharm Sci, 50, 2013, p. 78.

39.WANG, G., MA, Y., WEI, Z., QI, M., Chem. Eng. J., 289, 2016, p.150. 40.GUPTA, R., SHEA, J., SCAIFE, C., SHURLYGINA, A., RAPOPORT, N., J. Contr. Rel., 212, 2015, p.70.

41.CAPRETTO, L., MAZZITELLI, S., COLOMBO, G., PIVA, R.,. PENOLAZZI, L, VECCHIATINI, R., ZHANG, X., NASTRUZZI, C., Int. J. Pharm., 440, 2013, p. 195.

42.PAUN, V. P., Central European Journal of Physics, 7, nr. 3, 2009, p.607.

43.PAUN, V. P., Mat. Plast., 44, no. 4, 2007, p. 393.

44.PAUN, V. P., Mat. Plast., 43, no.1, 2006, p. 57.

45.PAUN, V. P., Mat. Plast., 45, no.1, 2008, p.57.

46. PAUN, V. P., Mat. Plast., 40, no. 1, 2003, p. 25.

47.PAUN, V. P., Mat. Plast., 40, no. 2, 2003, p. 81.

48.PUSCA, S., PAUN, M.A., TOMA, C., Mat. Plast., 44, no. 1, 2007, p.39. 49.FESSI, H., PUISIEUX, F., DEVISSAGUET, J. P., AMMOURY, N., BENITA, S., Int. J. Pharm., 55, 1989, p. R1. 
50.HOLBAN, M., IUREA (RATA), D. M., POPA, M. in Polymeric Nanomedicines edited by M. Popa and C. V. Uglea, Bentham Science Publishers, 2013, pp 412.

51.GOWTHAMARAJAN K., SINGH, S. K., Dissolut. Technol., 17, 2010, p. 24.

52.SANGHVI, R., NARAZAKI, R., MACHATHA, S. G., YALKOWSKY, S. H., AAPS PharmSciTech, 9, 2008, p.366.

53.J OUYBAN, A., FAKHREE M. A. A.,SHAYANFAR A., J. Pharm. Pharmaceut. Sci., 13, 2010, p. 524.

54.KALEPU, S., NEKKANTI, V., Acta Pharm Sin B, 5, 2015, p.442.

55.HAMILTON, M. A., RUSSO, R. C., THURSTON, R.V., Environ. Sci. Technol., 12, 1978, p. 417.

56.J ORGENSEN, J. H., TURNIDGE, J. D., Manual of clinical microbiology 9th ed. Edited by MURRAY P. R., BARON E. J., JORGENSEN J. H., LANDRY M. L., PFALLER M. A., ASM Press, 2007, p. 1152.
57.CHEPTEA, C., SUNEL, V., PROFIRE, L., POPA, M., LIONTE, C., Bull. Instit. lasi s.ll.c., 55, 2009, p. 89.

58.GUZMÁN, M. L., MANZO, R. H., OLIVERA, M. E., Mol. Pharm., 9, 2012, p. 2424

59.J OSHI, G. V., KEVADIYA, B. D., BAJAJ , H. C., Drug Dev. Ind. Pharm., 36, 2010, p. 1046.

60.KALIMUTHU S., YADAV, A. V., Int. J. Pharm. Tech. Res., 1, 2009, p. 179.

61.MORA-HUERTAS, C. E., FESSI, H., ELAISSARI, A., Int. J . Pharm., 385, 2010, p.113.

62.ROY, S., PAL, K., ANIS, A., PRAMANIK, K., PRABHAKAR, B., Desig. Monom. Polym., 12, 2009, p. 483.

63.HARDING, S. E., DAVIS, S. S., DEACON, M. P., FIEBRIG I., Biotechnol. Genet. Eng. Rev., 16, 1999, p. 41.

64. HODGE, H. C., STERNER J. H., Am. Ind. Hyg. Assoc. J., 10, 1949, p. 93.

Manuscris received: 2.12 .2016 